\title{
Impact of AT2-receptor stimulation on vascular biology, kidney function, and blood pressure
}

\author{
This article was published in the following Dove Press journal: \\ Integrated Blood Pressure Control \\ 21 November 2013 \\ Number of times this article has been viewed
}

\author{
Leon A Danyel' \\ Patrick Schmerler' \\ Ludovit Paulis ${ }^{1-3}$ \\ Thomas Unger ${ }^{4}$ \\ U Muscha Steckelings ${ }^{1,5}$ \\ 'Center for Cardiovascular Research, \\ Institute of Pharmacology, Charité \\ Medical Faculty, Berlin, Germany; \\ ${ }^{2}$ Institute of Pathophysiology, Faculty \\ of Medicine, Comenius University, \\ Bratislava, Slovak Republic; ${ }^{3}$ Institute \\ of Normal and Pathological \\ Physiology, Slovak Academy of \\ Sciences, Bratislava, Slovak Republic; \\ ${ }^{4}$ CARIM, Maastricht University, \\ Maastricht, the Netherlands; Institute \\ of Molecular Medicine, Department of \\ Cardiovascular and Renal Physiology, \\ University of Southern Denmark, \\ Odense, Denmark
}

Correspondence: $U$ Muscha Steckelings Institute of Molecular Medicine, Department of Cardiovascular and Renal Physiology, University of Southern Denmark, JB Winsløws Vej 2I-3, 5000 Odense C, Denmark

$\mathrm{Tel}+4565503760$

Fax +45 66133479

Email usteckelings@health.sdu.dk

\begin{abstract}
The angiotensin type 2 receptor (AT2R) and the receptor MAS are receptors within the renin-angiotensin system, which mediate tissue-protective actions such as anti-inflammation, antifibrosis, and antiapoptosis. In recent years, several programs have been launched in order to develop drugs that act as agonists on the AT2R or MAS to take therapeutic advantage of the protective and regenerative properties of these receptors. This review article will focus on recent data obtained in preclinical animal and in vitro models with new AT2R-agonistic molecules (Compound 21 and $\beta$-amino acid substituted angiotensin II) and with relevance for blood pressure (BP) regulation or hypertensive end-organ damage. These data will include studies on vasodilation/vasoconstriction in isolated resistance arteries ex vivo, studies on kidney function, studies on vascular remodeling, and studies that measured the net effect of AT2R stimulation on BP in vivo. Current data indicate that although AT2R stimulation causes vasodilation ex vivo and promotes natriuresis, it does not alter BP levels in vivo acutely - at least as long as there is no additional low-dose blockade of AT1R. However, AT2R stimulation alone is able to attenuate hypertension-induced vascular remodeling and reduce arterial stiffening, which in more chronic settings and together with the natriuretic effect may result in modest lowering of BP. We conclude from these preclinical data that AT2R agonists are not suitable for antihypertensive monotherapy, but that this new future drug class may be beneficial in combination with established antihypertensives for the treatment of hypertension with improved protection from end-organ damage.
\end{abstract}

Keywords: renin-angiotensin system, AT2-receptor, vasodilation, blood pressure, kidney function, vascular remodeling

\section{Introduction}

The renin-angiotensin system (RAS) is essentially involved in the control of blood pressure (BP) and body volume. ${ }^{1}$ Angiotensin II (Ang II), acting via the angiotensin type 1 receptor (AT1R), causes vasoconstriction as well as sodium and water retention. ${ }^{2}$ Furthermore, it is involved in the pathogenesis of hypertensive and diabetic end-organ damage by promoting inflammation and fibrosis. Pharmacological interference with the RAS by direct renin inhibitors, angiotensin-converting enzyme (ACE) inhibitors, or AT1R blockers (ARB) is a common therapeutic approach for the treatment of hypertension. ${ }^{3}$ In addition, ACE inhibitors and ARBs are standard treatment for heart failure and diabetic nephropathy.

In the recent past, research on potential new drug targets within the RAS and the development of respective novel drugs have gained significant momentum. ${ }^{46}$ These current efforts mainly aim at making therapeutic use of the so-called protective RAS, 
which comprises the AT2R and the ACE2-angiotensin-(1-7) (Ang-[1-7])-MAS axis. Both the AT2R and the receptor MAS mediate a broad array of tissue-protective effects, including anti-inflammation, antifibrosis, antiapoptosis, neuroprotection, favorable metabolic effects, and vasodilation. In particular, their ability to counteract vasoconstriction, inflammation, and fibrosis makes the AT2R and MAS potential drug targets for the treatment of hypertension and related end-organ damage. Interestingly, there seems to be a positive feedback loop within the protective RAS because, as has been published very recently, the expression of ACE2, Ang-(1-7), and MAS, as well as ACE2 activity, were increased in the kidneys of obese Zucker rats treated for 2 weeks with the AT2R agonist CGP 42112A. ${ }^{7}$

Regarding the AT2R, there are currently three types of new agonistic molecules with the potential for drug development: 1) the nonpeptide small molecule agonist Compound 21 (C21; Vicore Pharma, Gothenburg, Sweden, www.vicorepharma.com),${ }^{8}$ 2) the cyclic Ang II derivative (one amino acid exchanged for another, unknown [unpublished] amino acid) LP2-3 (Lanthio Pharma, Groningen, the Netherlands, www.lanthiopep.nl), ${ }^{9}$ and 3) a group of Ang II derivatives in which individual amino acids in the sequence of native Ang II are substituted by the respective $\beta$-amino acid. ${ }^{10} \mathrm{C} 21$ is currently in the final stage of preclinical development and is expected to enter clinical testing in 2014, the status of LP2-3 is unknown, and the $\beta$-amino acid substituted molecules are currently used only for academic purposes.

This review article will discuss physiology and potential therapeutic use of the AT2R with a focus on its role in BP regulation and hypertensive end-organ damage.

\section{Vasodilation and blood pressure}

Stimulation of the AT2R has been shown to act in a vasodilatory way in various species and multiple vascular beds such as mesenteric, ${ }^{11-15}$ renal, ${ }^{16-18}$ coronary, ${ }^{19}$ cerebral, ${ }^{20}$ cutaneous, ${ }^{21}$ and uterine arteries. ${ }^{22,23}$ In addition, AT2R knockout mice exhibit higher basal BP levels than wild-type mice, and they react with a stronger increase in BP to infusion of Ang II. ${ }^{24,25}$ Conversely, in mice overexpressing AT2Rs in the vasculature, the pressor response to Ang II is markedly impaired. ${ }^{26}$

Vasodilation was also shown for more recently developed AT2R agonists such as the first nonpeptide agonist $\mathrm{C} 21^{8}$ or for the new peptide agonists generated by substituting individual amino acids in the sequence of native Ang II by the respective $\beta$-amino acid (Table 1). ${ }^{9}$ Vasodilation in response to these new ligands at concentrations between $10^{-11}$ and $10^{-6} \mathrm{M}$ was observed in aorta from normotensive mice or hypertensive rats and in mouse mesenteric arteries in an AT2R-dependent manner, because these effects could be blocked by the AT2R antagonist PD 123319. ${ }^{10,27}$ Vasodilation in response to $\mathrm{C} 21$ was also reported by Verdonk et a ${ }^{28}$ in coronary, iliac, and mesenteric arteries of rats and mice; however, only at concentrations between $10^{-6}$ and $10^{-3} \mathrm{M}$. This vasodilatory response of $\mathrm{C} 21$ was unrelated to the AT2R because it could not be blocked by the AT2R antagonist PD 123319, which with $1 \mu \mathrm{mol} / \mathrm{L}$, however, was underdosed for most tested concentrations of $\mathrm{C} 21$, and because it was absent in AT2R-deficient mice. The mechanism of AT2R-unrelated vasodilation in response to C21 is still unknown but may involve blockade of calcium transport into the cell. Vasodilation caused by very high concentrations of $\mathrm{C} 21$ was preceded by a short vasoconstriction, which was obviously due to AT1R stimulation, because it could be blocked by AT1R antagonists. ${ }^{28}$ This observation was not surprising, as Bosnyak et a ${ }^{27}$ had previously described that $\mathrm{C} 21$ stimulates the AT1R at very high concentrations, resulting in a rise in BP. In general, most small molecule drugs lose specificity at concentrations $>1 \mu \mathrm{M}$ or even lower. Well-known examples are $\beta 2$-receptor mimetics used for the treatment of asthma, or $\beta 1$-receptor blockers used for the treatment of hypertension, both of which bind to the respective other receptor subtype at high concentrations. For example, the Ki of the $\beta 2$-receptor mimetic salmeterol, which possesses the highest selectivity of this drug class, is $24.6 \mathrm{nM}$ for the $\beta 2$-receptor and $1,600 \mathrm{nM}$ for the $\beta 1$-receptor; the selective $\beta 1$-receptor blocker metoprolol has a Ki of $47 \mathrm{nM}$ for the $\beta 1$-receptor and of $2.960 \mathrm{nM}$ for the $\beta 2$-receptor. ${ }^{29,30} \mathrm{With}$ a Ki for the AT2R of $0.4 \mathrm{nM}$ ( $2 \mathrm{nM}$ for the human receptor) and $>10,000 \mathrm{mM}$ for the AT1R, the selectivity of C21 is not any worse than selectivity of so-called selective $\beta$-blockers or $\beta 2$-receptor mimetics.

It seems logical that a hormone or drug that is able to cause vasodilation in isolated blood vessels would also be able to lower $\mathrm{BP}$ in animals and/or humans, as the vascular tone in resistance arteries is a major determinant of systolic BP. However, for the AT2R, this seems not to be the case (Table 2). Several studies using peptide or nonpeptide AT2R agonists, including the new molecules discussed previously, demonstrated that an AT2Rmediated decrease in BP occurred only when there was a concomitant low-dose blockade of AT1Rs. For example, this was shown by the Carey et $\mathrm{al}^{31}$ in conscious, normotensive Sprague Dawley rats and by Barber et $\mathrm{al}^{32}$ in conscious, normotensive Wistar Kyoto and spontaneously hypertensive rats (SHR) in a PD 123319-reversible manner. ${ }^{10,27}$ The only exceptions were BP measurements in anesthetized rats, which were part of the first 
Table I Effects of new AT2R agonists on vascular tone ex vivo

\begin{tabular}{|c|c|c|c|c|c|}
\hline AT2 agonist & Type of vessel & Species & Effective concentration & Result & Reference \\
\hline$\beta$-substituted & Aorta & Mouse & $10^{-12}$ to $10^{-6} \mathrm{M}$ & Vasodilation in presence of ATIR & 8 \\
\hline Ang peptides & & & & blocker & \\
\hline$\beta$-substituted & Aorta & Mouse & $10^{-12}$ to $10^{-6} \mathrm{M}$ & Vasodilation in absence of ATIR & 8 \\
\hline Ang peptides & & & & blocker & \\
\hline \multirow[t]{2}{*}{$\mathrm{C} 21$} & Aorta & Mouse & $10^{-10}$ to $10^{-6} \mathrm{M}$ & Vasodilation in presence of ATIR & 14 \\
\hline & & & & blocker & \\
\hline \multirow[t]{2}{*}{$\mathrm{C} 21$} & Aorta & SHR & $10^{-11}$ to $10^{-6} \mathrm{M}$ & Vasodilation in presence of ATIR & 14 \\
\hline & & & & blocker & \\
\hline \multirow[t]{2}{*}{$\mathrm{C} 2 \mathrm{I}$} & Mesenteric artery & Mouse & $10^{-10}$ to $10^{-6} \mathrm{M}$ & Vasodilation in presence of ATIR & 14 \\
\hline & & & & blocker & \\
\hline \multirow[t]{2}{*}{$\mathrm{C} 2 \mathrm{I}$} & Aorta & Mouse & $10^{-09}$ to $10^{-6} \mathrm{M}$ & Vasodilation in absence of ATIR & 14 \\
\hline & & & & blocker & \\
\hline \multirow[t]{2}{*}{ C2I } & Coronary & Human & $10^{-06}$ to $10^{-4} \mathrm{M}$ & Vasodilation in absence of ATIR & 15 \\
\hline & microartery & & & blocker & \\
\hline \multirow[t]{2}{*}{ C2I } & Iliac artery & Wistar rat & $10^{-07}$ to $10^{-4} \mathrm{M}$ & Vasodilation in absence of ATIR & 15 \\
\hline & & & & blocker & \\
\hline \multirow[t]{2}{*}{$\mathrm{C} 21$} & Mesenteric artery & Wistar rat & $10^{-07}$ to $10^{-4} \mathrm{M}$ & Vasodilation in absence of ATIR & 15 \\
\hline & & & & blocker & \\
\hline \multirow[t]{2}{*}{ C2I } & Mesenteric artery & SHR & $10^{-08}$ to $10^{-4} \mathrm{M}$ & Vasodilation in absence of ATIR & 15 \\
\hline & & & & blocker & \\
\hline $\mathrm{C} 2 \mathrm{I}$ & Iliac artery & Wistar rat & $10^{-10}$ to $10^{-4} \mathrm{M}$ & No effect & 15 \\
\hline $\mathrm{C} 2 \mathrm{I}$ & Iliac artery & SHR & $10^{-05}$ to $10^{-4} \mathrm{M}$ & Vasoconstriction & 15 \\
\hline \multirow[t]{2}{*}{$\mathrm{C} 2 \mathrm{I}$} & Iliac artery & Mouse & $10^{-07}$ to $10^{-4} \mathrm{M}$ & Vasodilation in absence of ATIR & 15 \\
\hline & & & & blocker & \\
\hline \multirow[t]{2}{*}{ C2I } & Iliac artery & AT2-KO & $10^{-07}$ to $10^{-4} \mathrm{M}$ & Vasodilation in absence of ATIR & 15 \\
\hline & & & & blocker & \\
\hline $\mathrm{C} 2 \mathrm{I}$ & Coronary arteries & Wistar rat & $10^{-04}$ to $10^{-3} \mathrm{M}$ & Initial inhibition of coronary flow & 15 \\
\hline $\mathrm{C} 2 \mathrm{I}$ & Coronary arteries & Wistar rat & $10^{-3} \mathrm{M}$ & Increase in coronary flow & 15 \\
\hline $\mathrm{C} 2 \mathrm{I}$ & Coronary arteries & SHR & $10^{-05}$ to $10^{-3} \mathrm{M}$ & Initial inhibition of coronary flow & 15 \\
\hline $\mathrm{C} 2 \mathrm{I}$ & Coronary arteries & SHR & $10^{-04}$ to $10^{-3} \mathrm{M}$ & Increase in coronary flow & 15 \\
\hline $\mathrm{C2I}$ & Coronary arteries & $\begin{array}{l}\text { Mouse (wild-type } \\
\text { and AT2-KO) }\end{array}$ & $10^{-10}$ to $10^{-3} \mathrm{M}$ & No effect & 15 \\
\hline \multirow[t]{2}{*}{$\mathrm{C} 2 \mathrm{I}$} & Mesenteric & SHR & $10^{-10}$ to $10^{-5} \mathrm{M}$ & Vasodilation in presence of ATIR & 32 \\
\hline & arteries & & & blocker & \\
\hline
\end{tabular}

Abbreviations: AT2R, angiotensin type 2 receptor; KO, knockout; SHR, spontaneously hypertensive rats; ATIR, angiotensin type I receptor.

description of design and synthesis of C21. ${ }^{8}$ In this study, C21 caused a fall in BP of up to $25 \mathrm{mmHg}$. However, it has to be noted that anesthesia probably caused unphysiological effects of this pharmacological intervention with the RAS, which is activated by anesthesia. ${ }^{33}$

The observation that AT2R stimulation lowers BP only in the presence of low-level AT1R blockade indicates that in vivo a continuous angiotensinergic tone mediated via the AT1R seems dominant over any vasodilatory effect of AT2Rs. Consequently, AT2R agonists will most likely not become antihypertensive drugs suitable for monotherapy. However, due to their tissueprotective effects discussed as follows, the combination of established antihypertensives with AT2R agonists may result in better long-term prevention of hypertensive end-organ damage. Moreover, long-term therapy with AT2R agonists may have a modest BP-lowering effect due to structural changes of the vessel walls (see paragraph about "Vascular remodeling" below) and due to a recently described diuretic effect (see paragraph about "AT2 receptor activation in renal physiology and disease" below). ${ }^{34-36}$ AT2R stimulation may further act antihypertensive by CNS related mechanisms that become apparent only if $\mathrm{C} 21$, which crosses the blood-brain barrier only very poorly, is applied intracerebroventricularly. ${ }^{37}$

Normal pregnancy and preeclampsia are conditions during which expression of components of the RAS is altered in a way that the peripheral and tissue RAS are activated. ${ }^{38}$ In preeclampsia in patients or in respective animal models, the ratio of expression of AT1R and AT2R changes is favor of the AT1R in placental and uterine tissue and arteries. ${ }^{39-41}$ The AT2R has been described to act in a vasodilatory manner and to counteract the enhanced vasoconstrictive effect of Ang II via the AT1R during pregnancy. ${ }^{22}$ Thus, it can 
Table 2 Effects of new AT2R agonists on blood pressure

\begin{tabular}{|c|c|c|c|c|}
\hline AT2 agonist & Species/strain & Dosage & Result & Reference \\
\hline$\beta$-substituted & SHR & I5 pmol/kg/min IV & MAP $\sqrt{ }$ only in presence of a low-dose & 8 \\
\hline Ang peptides & & & ATIR blocker & \\
\hline \multirow[t]{2}{*}{ C2I } & SHR & $100 / 300 \mathrm{ng} / \mathrm{kg} / \mathrm{min} \mathrm{IV}$ & MAP $\sqrt{ }$ only in presence of a low-dose & 14 \\
\hline & & & ATIR blocker; AT2-dependent & \\
\hline $\mathrm{C} 2 \mathrm{I}$ & SHR & $\mathrm{I}, 000 \mathrm{ng} / \mathrm{kg} / \mathrm{min} \mathrm{IV}$ & MAP 仓; ATIR-dependent & 14 \\
\hline $\mathrm{C} 21$ & Wistar-Kyoto rats & $50-300 \mathrm{ng} / \mathrm{kg} / \mathrm{min}$ IV & No effect & 14 \\
\hline $\mathrm{C} 21$ & Sprague Dawley rats & $100-300$ ng/kg/min IV & No effect & 22 \\
\hline $\mathrm{C} 21$ & Obese Zucker rats & $\mathrm{I} \mu \mathrm{g} / \mathrm{kg} / \mathrm{min} \mathrm{IV}$ & No effect & 23 \\
\hline $\mathrm{C} 21$ & Sprague Dawley rats & $0.5 \mu \mathrm{g} / \mu \mathrm{I} / \mathrm{h} \mathrm{ICV}$ & MAP $\Omega$ by central mechanisms & 24 \\
\hline $\mathrm{C} 21$ & L-NAME-induced hypertension & $0.3 \mathrm{mg} / \mathrm{kg}$ BW IP & No effect & 31 \\
\hline $\mathrm{C} 21$ & SHR & I mg/kg BW PO & $\begin{array}{l}\text { Increase after I week; no effect } \\
\text { in weeks } 2-5\end{array}$ & 32 \\
\hline $\mathrm{C} 21$ & $2 \mathrm{KIC}$ hypertension & $0.3 \mathrm{mg} / \mathrm{kg}$ BW IP & No effect & 39 \\
\hline $\mathrm{C} 21$ & SHR-SP & $10 \mathrm{mg} / \mathrm{kg} /$ day extended release & No effect & 40 \\
\hline & & from $0.5 \% \mathrm{Na}$-carboxymethylcellulose & & \\
\hline C21 & Wistar rats & $0.03 / 0.3 \mathrm{mg} / \mathrm{kg} \mathrm{BW} \mathrm{IP}$ & No effect & 59 \\
\hline $\mathrm{C} 21$ & C57BI-6 & $\mathrm{I} / 3 / 10 \mu \mathrm{g} / \mathrm{kg}$ BW IP & No effect & 60 \\
\hline $\mathrm{C} 21$ & Obese Zucker rats & $300 \mu \mathrm{g} / \mathrm{kg} /$ day IP & No effect & 61 \\
\hline $\mathrm{C} 21$ & KK-Ay mice & $10 \mu g / k g$ BW IP & No effect & 62 \\
\hline
\end{tabular}

Abbreviations: 2KIC, two-kidney, one-clip rat model; AT2R, angiotensin type 2 receptor; BW, body weight; ICV, intracerebroventricularly; IP, intraperitoneally; IV,

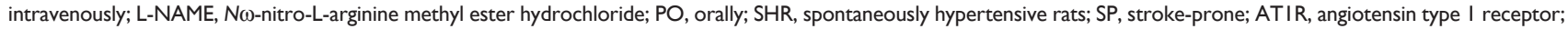
MAP, mean arterial pressure.

be speculated that the relative deficiency in AT2R during preeclampsia may contribute to the development of hypertension. In a recent study, Hladunewich et $\mathrm{al}^{42}$ could, in fact, demonstrate that there is a strong correlation between AT1R/ $\mathrm{AT} 2 \mathrm{R}$ ratio and the change in $\mathrm{BP}$ (the higher the ratio, the stronger the increase in BP; $r=0.54$ ) in women with previous severe preeclampsia who received a graded infusion of Ang II (1-3 ng/ $\mathrm{kg} / \mathrm{min})$. The importance of the role of the AT2R for the development of preeclampsia still needs confirmation, but if it should turn out to really be of importance, AT2R agonists may be a treatment option of interest, although under "normal" conditions they do not lower BP.

\section{Vascular remodeling}

Chronically elevated BP causes an inflammatory response followed by excess synthesis and accumulation of extracellular matrix mainly in the left cardiac ventricle, the kidneys, and the vascular wall. This fibrotic response to hypertension leads to deteriorated organ function and manifests as heart failure, renal disease, or vascular stiffening, the latter two of which reinforce the development of hypertension, thus establishing a vicious circle. ${ }^{43}$

Early studies on the role of AT2R stimulation on vascular remodeling could show that the beneficial effects of ARBs were, at least in part, due to indirect AT2R stimulation (use of ARBs leads to an increase in renin release and thus a rise in angiotensin II levels, which, in turn, stimulates the unopposed AT2Rs; ARB-induced Ang II levels are, however, much lower than pharmacological AT2 agonist levels), as these effects could be reversed by blockade of AT2Rs. ${ }^{44,45}$ Further indirect evidence for a favorable role of AT2Rs in vascular remodeling is coming from studies in AT2Rdeficient mice, which responded with augmented vascular hypertrophy of coronary, aortic, and femoral arteries to chronically elevated $\mathrm{BP}^{46-48}$

The impact of direct AT2R stimulation on hypertensioninduced vascular remodeling was studied recently in two studies in which C21 was applied orally to rats (Table 3). ${ }^{49,50}$

Table 3 Effects of new AT2R agonists on vascular remodeling

\begin{tabular}{lllll}
\hline AT2 agonist & Species/model & Dosage & Result & Reference \\
\hline C2I & L-NAME-induced & $0.3 \mathrm{mg} / \mathrm{kg} \mathrm{BW} \mathrm{IP}$ & $\begin{array}{l}\text { Reduced aortic wall thickness and collagen content; } \\
\text { lowered pulse wave velocity }\end{array}$ \\
hypertension & & $\begin{array}{l}\text { Reduced mesenteric artery stiffness; reduced aortic } \\
\text { collagen and fibronectin content; lowered oxidative stress }\end{array}$ & 32 \\
\hline
\end{tabular}

Abbreviations: AT2R, angiotensin type 2 receptor; BW, body weight; IP, intraperitoneally; L-NAME, N $\omega$-nitro-L-arginine methyl ester hydrochloride; PO, orally; SHR, spontaneously hypertensive rats. 
The authors of these studies used different models of hypertension: ie, stroke-prone spontaneously hypertensive rats (SHR-SP) in one study, ${ }^{50}$ and inhibition of endothelial nitric oxide synthase by application of $N \omega$-nitro-L-arginine methyl ester hydrochloride (L-NAME) in the other study. ${ }^{49}$ In both studies, the effect of AT2R stimulation was compared with the effect of an ARB alone or the combination of both. The main finding of both studies was that treatment with an AT2R agonist widely prevented the development of vascular hypertrophy and fibrosis. Remarkably, this reversal of hypertension-induced pathology was achieved without any significant effect on BP: ie, although BP stayed elevated in C21-treated rats, vascular remodeling was almost completely prevented. ${ }^{49,50}$ The preventive effect of AT2R stimulation on vascular remodeling was shown in both studies to be related to a decrease in collagen deposition. Moreover, in our study in L-NAME-induced hypertension in rats, we measured pulse wave velocity, a marker for arterial stiffness and independent predictor of cardiovascular risk in patients, and we could again show that this indicator of vascular remodeling, which was increased in vehicle-treated hypertensive animals, was significantly attenuated in C21-treated, (still) hypertensive animals. ${ }^{49}$

BP in our study was not significantly changed by treatment with $\mathrm{C} 21$, but there was a trend toward a reduction in BP, which may have been a result of reduced arterial stiffness. $^{49}$

\section{Kidney function \\ AT2-receptor deficiency in renal disease and injury}

Considering the ubiquitous expression of the AT2R in fetal kidney, it may be surprising that AT2R knockout mice show no renal abnormalities in histology. ${ }^{24,51}$ However, obvious differences in disease progression in AT2R knockout mice when compared with wild-type mice were revealed in the renal ablation model of renal injury. ${ }^{51}$ Aggravated glomerular damage and impairment of renal function were shown in AT2R-deficient mice compared with wild-type mice, subsequently culminating in higher overall mortality. Moreover, albuminuria in knockout mice was pronounced and renal macrophage infiltration of glomerulus and interstitium increased compared with wild-type mice. Benndorf et $\mathrm{al}^{51}$ ruled out systolic BP differences, podocyte or basal membrane damage, or upregulation of AT1Rs as possible causes for enhanced renal injury. Nonetheless, they elucidated one of the possible underlying mechanisms of disease progression in AT2R-deficient mice by showing a significant upregulation of asymmetric dimethylarginine, an endogenous inhibitor of nitric oxide synthase, in the knockout group, suggesting that the impairment in synthesis of nitric oxide may account for the aggravation of glomerular damage observed.

In accordance with these results, aggravated renal injury was observed in unilateral ureteral obstruction of AT2R-deficient mice, comprising severe interstitial fibrosis and greater abundance of fibroblasts and myofibroblasts in ipsilateral kidneys. ${ }^{52}$

Moreover, in a model of type 1 diabetes in mice, AT2R knockout animals exhibited accelerated development of diabetic nephropathy. ${ }^{53}$ Extracellular matrix (ECM) protein accumulation was measured by quantification of periodic acid-Schiff and Masson trichrome staining, as well as realtime quantitative polymerase chain reaction analysis of renal collagen IV messenger ribonucleic acid expression. Terminal deoxynucleotidyl transferase dUTP nick end labeling assay was performed to semiquantify tubular apoptosis between groups. ECM accumulation and renal expression of collagen IV were significantly enhanced in nondiabetic AT2R knockout mice compared with nondiabetic controls. Additionally, tubular apoptosis was significantly increased in nondiabetic AT2R knockout mice. Accordingly, similar observations of increased ECM production and tubular apoptosis in AT2R-deficient animals were made in diabetic knockout animals when compared with wild-type mice, although values reached significance only for Masson trichrome staining arbitrary units. Chang et $\mathrm{al}^{53}$ proposed that an increase in Heme oxygenase 1 expression, observed in proximal tubule cells of AT2R knockout mice, enhances oxidative stress. Moreover, an elevated ACE/ACE2 ratio in knockout animals could account for aggravation of renal injury during diabetic nephropathy.

It is important to note that deterioration of renal injury in AT2R-deficient mice may result from a persistent but yet unnoticed impairment in renal function that evolved during fetal development, due to the absence of the AT2R, which is usually expressed in high density during fetal life, and may not represent missing counter-regulatory actions of the receptor itself in the adult organism.

\section{AT2 receptor activation in renal physiology and disease}

So far, studies investigating the role of the AT2R in renal disease were conducted under 1) AT1R blockade with subsequent Ang II administration, 2) using the peptide agonist CGP 42112 , or 3) under AT2R blockade achieved by administration of PD 123319. Findings in this regard have been recently 
summarized and will not be further discussed in this review. ${ }^{54,55}$ Interpretation of results, however, is confounded by possible antagonistic effects of CGP 42112 and by agonistic effects of PD 123319 on the AT1R or even the AT2R, depending on timing and dosage. ${ }^{28,56}$ Since $\mathrm{C} 21$ became available for experimental research, data about the role of the AT2R in kidney function have become more consistent and unequivocally strengthen the idea of a protective role of the AT2R in renal disease and of a natriuretic effect of AT2R stimulation (Table 4).

In Sprague Dawley rats, graded infusion of C21 (peak dosage: $300 \mathrm{ng} / \mathrm{kg} / \mathrm{min}$ ) significantly enhanced renal blood flow by simultaneously reducing renal vascular resistance in both female and male animals. ${ }^{35}$ In addition, urine flow, urinary sodium excretion, and fractional sodium excretion showed a significant increase when compared with vehicletreated groups. All effects observed were abolished by concomitant administration of PD 123319. Interestingly, glomerular filtration rate remained stable in the C21 group, albeit the presence of renal vasodilation suggesting that the C21-induced increase in natriuresis is altered due to an effect on tubular function, but not due to hemodynamic effects. All effects were BP independent, as there was no statistically significant difference in BP between vehicle- and C21-treated animals. However, there was a small but significant difference between the C21- and the C21 plus PD 123319-treated animals (BP in PD 123319-treated animals being lower), but from these data it cannot be decided whether this difference was due to an effect of C21 or of PD 123319 or of both. ${ }^{35}$

An AT2R-dependent but BP-independent natriuretic effect of C21 was further described recently in obese Zucker rats. ${ }^{36}$ In analogy to the study by Hillard et al, ${ }^{35}$ glomerular filtration rate remained unchanged in these animals, speaking again for a direct, tubular effect of $\mathrm{C} 21$.

In the two-kidney, one-clip rat model of hypertension (2K1C), Matavelli et al ${ }^{57}$ evaluated the effects of AT2R stimulation in early renal inflammation. In $2 \mathrm{~K} 1 \mathrm{C}$ rats, kidney perfusion is reduced by unilateral clipping of the renal artery. Inflammatory markers of the subsequently developing ischemia were determined by in vivo recovery levels of renal intestinal fluid. Animals received vehicle, C21 (0.3 mg/kg/day, intraperitoneally), PD 123319 (10 mg/kg/day, osmotic minipump), or C21 plus PD 123319 over the 4-day course of the study. Unilateral stricture of the renal artery led to a significant increase in AT2R protein expression, which was even further enhanced in the C21 group but abolished by administration of PD 123319. Expression of tumor necrosis factor (TNF)- $\alpha$, transforming growth factor (TGF)- $\beta 1$, and interleukin (IL)-6 messenger ribonucleic acid and their renal interstitial fluid (RIF) recovery rates were significantly elevated in $2 \mathrm{~K} 1 \mathrm{C}$ compared with sham-operated animals. In contrast, nitric oxide and cyclic guanosine monophosphate RIF recovery rates were significantly reduced. Treatment with $\mathrm{C} 21$ reduced TNF $\alpha$, TGF $\beta 1$, and IL-6 expression and, moreover, increased RIF recovery rates for nitric oxide and cyclic guanosine monophosphate. Extensive inflammatory cell infiltration observed by histological (hematoxylin/eosin) staining of $2 \mathrm{~K} 1 \mathrm{C}$ renal cortex and medulla was significantly reduced with $\mathrm{C} 21$ treatment when compared with the vehicle group. These effects were only partially inhibited by the AT2R antagonist PD 123319. ${ }^{57}$

SHR-SPs represent an animal model of hypertension, characterized by the progressive development of renal damage and brain abnormality against the background of elevated Ang II blood levels. Oral treatment with C21 (peak dosage group: $10 \mathrm{mg} / \mathrm{kg}$, suspended release from $0.5 \%$ sodium carboxymethylcellulose) significantly delayed the development of proteinuria and prevented the accumulation of high-molecular-weight proteins, which present markers of renal inflammation, in 24-hour urine electrophoresis. ${ }^{58}$ Although plasma renin activity increased significantly in the vehicle group, plasma renin activity remained at basal levels in animals treated with C21. Finally, analysis of kidney histopathology revealed reduced renal lesions (attenuation of vascular lesions, tubular damage, luminal cast formation, glomerular sclerosis, inflammatory infiltrates) and attenuated renal macrophage infiltration in rats treated with $\mathrm{C} 21$.

Table 4 Effects of new AT2R agonists on kidney function and pathology

\begin{tabular}{lllll}
\hline AT2 agonist & Species/strain & Dosage & Result & Reference \\
\hline C2I & Sprague Dawley rats & $100-300 \mathrm{ng} / \mathrm{kg} / \mathrm{min} \mathrm{IV}$ & Natriuresis, GFR unchanged & 22 \\
C2I & Obese Zucker rats & $5 \mu \mathrm{g} / \mathrm{kg} / \mathrm{min} \mathrm{IV}$ & Natriuresis, GFR unchanged & 23 \\
C2I & $2 \mathrm{KIC}$ hypertension & $0.3 \mathrm{mg} / \mathrm{kg} \mathrm{BW} \mathrm{IP}$ & Attenuated renal inflammation & 39 \\
C2I & SHR-SP & $10 \mathrm{mg} / \mathrm{kg} /$ day in $0.5 \%$ carboxymethyl-cellulose & Attenuation of albuminuria & 40 \\
C2I & SHR-SP & $10 \mathrm{mg} / \mathrm{kg} /$ day in $0.5 \%$ carboxymethyl-cellulose & Attenuated renal fibrosis and inflammation & 40 \\
C2I & Obese Zucker rats & $300 \mu \mathrm{g} / \mathrm{kg} /$ day IP & Attenuated renal inflammation & $6 \mathrm{I}$ \\
\hline
\end{tabular}

Abbreviations: 2KIC, two-kidney, one-clip rat model; AT2R, angiotensin type 2 receptor; BW, body weight; GFR, glomerular filtration rate; IP, intraperitoneally; IV, intravenously; SHR, spontaneously hypertensive rats; SP, stroke-prone. 
Furthermore neoexpression of vimentin, a marker of tubulointestinal injury, was completely prevented by AT2R stimulation with $\mathrm{C} 21 .^{58}$

\section{Summary and conclusion}

AT2R stimulation elicits effects on several physiological mechanisms, which contribute to the regulation of BP. Specifically, AT2R agonists induce vasodilation in isolated vessels ex vivo and they enhance natriuresis in vivo. Furthermore, in hypertensive rats, AT2R stimulation attenuates arterial stiffening. Nevertheless, in vivo BP is not altered acutely and only modestly chronically, the latter usually not reaching statistical significance. The lack of acute effect is probably due to some kind of counter-regulatory mechanism(s), which has not been characterized yet, but may involve activation of the "classic" RAS (increased levels of Ang II acting on the AT1R) or of the sympathetic nervous system. The trend toward a reduction in BP in more chronic settings seems likely due to secondary mechanisms such as natriuresis leading to volume reduction or attenuated vascular remodeling, resulting in lower peripheral resistance.

According to these reviewed data from preclinical animal or in vitro/ex vivo studies, it is likely that AT2R agonists will be unsuitable as antihypertensive monotherapeutics in clinical use. However, they may enhance the effectiveness of other, established antihypertensives, and they may provide additive benefit in respect of protection from hypertensive end-organ damage. However, these assumptions need to be verified in future clinical studies.

\section{Disclosure}

U Muscha Steckelings received modest research support from Vicore Pharma. The other authors report no conflicts of interest in this work.

\section{References}

1. Steckelings UM, Unger T. The renin-angiotensin-aldosterone system. In: Mancia G, Grassi G, Kjeldsen SE, editors. Manual of Hypertension of the European Society of Hypertension. 1st ed. London, UK: Informa Healthcare; 2008:110-116.

2. De Gasparo M, Catt KJ, Inagami T, Wright JW, Unger T. International union of pharmacology. XXIII. The angiotensin II receptors. Pharmacol Rev. 2000;52(3):415-472.

3. Mentz RJ, Bakris GL, Waeber B, et al. The past, present and future of renin-angiotensin aldosterone system inhibition. Int $J$ Cardiol. 2013;167(5):1677-1687.

4. Bader M, Santos RA, Unger T, Steckelings UM. New therapeutic pathways in the RAS. $J$ Renin Angiotensin Aldosterone Syst. 2012;13(4): 505-508.

5. Ferreira AJ, Bader M, Santos RAS. Therapeutic targeting of the angiotensin-converting enzyme 2/angiotensin-(1-7)/Mas cascade in the renin-angiotensin system: a patent review. Expert Opin Ther Pat. 2012;22(5):567-574.
6. Steckelings UM, Paulis L, Unger T, Bader M. Emerging drugs which target the renin-angiotensin-aldosterone system. Expert Opin Emerg Drugs. 2011;16(4):619-630.

7. Ali Q, Wu Y, Hussain T. Chronic AT2 receptor activation increases renal ACE2 activity, attenuates AT1 receptor function and blood pressure in obese Zucker rats. Kidney Int. Epub July 3, 2013.

8. Wan Y, Wallinder C, Plouffe B, et al. Design, synthesis, and biological evaluation of the first selective nonpeptide AT2 receptor agonist. $J$ Med Chem. 2004;47(24):5995-6008.

9. Wagenaar GT, Laghmani el H, Fidder M, et al. Agonists of MAS oncogene and angiotensin II type 2 receptors attenuate cardiopulmonary disease in rats with neonatal hyperoxia-induced lung injury. Am J Physiol Lung Cell Mol Physiol. 2013;305(5):L341-L351.

10. Jones ES, Del Borgo MP, Kirsch JF, et al. A single beta-amino acid substitution to angiotensin II confers AT2 receptor selectivity and vascular function. Hypertension. 2011;57(3):570-576.

11. Dimitropoulou C, White RE, Fuchs L, Zhang H, Catravas JD, Carrier GO. Angiotensin II relaxes microvessels via the AT(2) receptor and $\mathrm{Ca}(2+)$-activated $\mathrm{K}(+)(\mathrm{BK}(\mathrm{Ca}))$ channels. Hypertension. 2001;37(2):301-307.

12. Katada J, Majima M. AT(2) receptor-dependent vasodilation is mediated by activation of vascular kinin generation under flow conditions. $\mathrm{Br} J$ Pharmacol. 2002;136(4):484-491.

13. Matrougui K, Lévy BI, Henrion D. Tissue angiotensin II and endothelin-1 modulate differently the response to flow in mesenteric resistance arteries of normotensive and spontaneously hypertensive rats. Br J Pharmacol. 2000;130(3):521-526.

14. Matrougui K, Loufrani L, Heymes C, Lévy BI, Henrion D. Activation of $\mathrm{AT}(2)$ receptors by endogenous angiotensin II is involved in flow-induced dilation in rat resistance arteries. Hypertension. 1999; 34(4 Pt 1):659-665.

15. Widdop RE, Matrougui K, Levy BI, Henrion D. AT2 receptor-mediated relaxation is preserved after long-term AT1 receptor blockade. Hypertension. 2002;40(4):516-520.

16. Arima S, Endo Y, Yaoita H, et al. Possible role of P-450 metabolite of arachidonic acid in vasodilator mechanism of angiotensin II type 2 receptor in the isolated microperfused rabbit afferent arteriole. J Clin Invest. 1997;100(11):2816-2823.

17. Endo Y, Arima S, Yaoita H, et al. Function of angiotensin II type 2 receptor in the postglomerular efferent arteriole. Kidney Int Suppl. 1997;63:S205-S207.

18. Endo Y, Arima S, Yaoita H, Tsunoda K, Omata K, Ito S. Vasodilation mediated by angiotensin II type 2 receptor is impaired in afferent arterioles of young spontaneously hypertensive rats. J Vasc Res. 1998;35(6): 421-427.

19. Batenburg WW, Garrelds IM, Bernasconi CC, et al. Angiotensin II type 2 receptor-mediated vasodilation in human coronary microarteries. Circulation. 2004;109(19):2296-2301.

20. Haberl RL. Role of angiotensin receptor subtypes in the response of rabbit brain arterioles to angiotensin. Stroke. 1994;25(7):1476-1479; discussion 1480 .

21. Savoia C, Touyz RM, Volpe M, Schiffrin EL. Angiotensin type 2 receptor in resistance arteries of type 2 diabetic hypertensive patients. Hypertension. 2007;49(2):341-346.

22. Pulgar VM, Yamashiro H, Rose JC, Moore LG. Role of the AT2 receptor in modulating the angiotensin-II contractile response of the uterine artery at mid gestation. J Renin Angiotensin Aldosterone Syst. 2011;12(3):176-183.

23. Widdop RE, Jones ES, Hannan RE, Gaspari TA. Angiotensin AT2 receptors: cardiovascular hope or hype? Br J Pharmacol. 2003;140(5): 809-824.

24. Hein L, Barsh GS, Pratt RE, Dzau VJ, Kobilka BK. Behavioural and cardiovascular effects of disrupting the angiotensin II type-2 receptor in mice. Nature. 1995;377(6551):744-747.

25. Ichiki T, Labosky PA, Shiota C, et al. Effects on blood pressure and exploratory behaviour of mice lacking angiotensin II type-2 receptor. Nature. 1995;377(6551):748-750. 
26. Tsutsumi Y, Matsubara H, Masaki H, et al. Angiotensin II type 2 receptor overexpression activates the vascular kinin system and causes vasodilation. J Clin Invest. 1999;104(7):925-935.

27. Bosnyak S, Welungoda IK, Hallberg A, Alterman M, Widdop RE, Jones ES. Stimulation of angiotensin AT2 receptors by the non-peptide agonist, Compound 21, evokes vasodepressor effects in conscious spontaneously hypertensive rats. Br J Pharmacol. 2010;159(3):709-716.

28. Verdonk K, Durik M, Abd-Alla N, et al. Compound 21 induces vasorelaxation via an endothelium- and angiotensin II type 2 receptorindependent mechanism. Hypertension. 2012;60(3):722-729.

29. Baker JG. The selectivity of beta-adrenoceptor agonists at human beta1-, beta2- and beta3-adrenoceptors. Br J Pharmacol. 2010;160(5): 1048-1061.

30. Griffin PP, Schubert-Zsilavecz M, Stark H. [Inhibitors of betaadrenergic receptors: Similarities and differences] Hemmstoffe von beta-Adrenozeptoren: Gemeinsamkeiten und Unterschiede. Pharmazie in Unserer Zeit. 2004;33(6):442-449. German.

31. Carey RM, Howell NL, Jin XH, Siragy HM. Angiotensin type 2 receptor-mediated hypotension in angiotensin type-1 receptor-blocked rats. Hypertension. 2001;38(6):1272-1277.

32. Barber MN, Sampey DB, Widdop RE. AT(2) receptor stimulation enhances antihypertensive effect of AT(1) receptor antagonist in hypertensive rats. Hypertension. 1999;34(5):1112-1116.

33. Efrati S, Berman S, Abu Hamad R, et al. Hyperglycaemia, inflammation, RAS activation: three culprits to blame for acute kidney injury emerging in healthy rats during general anaesthesia. Nephrology (Carlton). 2012;17(7):591-602.

34. Carey RM, Padia SH. Role of angiotensin at(2) receptors in natriuresis: intrarenal mechanisms and therapeutic potential. Clin Exp Pharmacol Physiol. 2013;40(8):527-534.

35. Hilliard LM, Jones ES, Steckelings UM, Unger T, Widdop RE, Denton KM. Sex-specific influence of angiotensin type 2 receptor stimulation on renal function: a novel therapeutic target for hypertension. Hypertension. 2012;59(2):409-414.

36. Ali Q, Hussain T. AT2 receptor non-peptide agonist C21 promotes natriuresis in obese Zucker rats. Hypertens Res. 2012;35(6):654-660.

37. Gao J, Zhang H, Le KD, Chao J, Gao L. Activation of central angiotensin type 2 receptors suppresses norepinephrine excretion and blood pressure in conscious rats. Am J Hypertens. 2011;24(6):724-730.

38. August P, Lenz T, Ales KL, et al. Longitudinal study of the reninangiotensin-aldosterone system in hypertensive pregnant women: deviations related to the development of superimposed preeclampsia. Am J Obstet Gynecol. 1990;163(5 Pt 1):1612-1621.

39. Anton L, Merrill DC, Neves LA, et al. The uterine placental bed renin-angiotensin system in normal and preeclamptic pregnancy. Endocrinology. 2009;150(9):4316-4325.

40. Anton L, Merrill DC, Neves LA, et al. Activation of local chorionic villi angiotensin II levels but not angiotensin (1-7) in preeclampsia. Hypertension. 2008;51(4):1066-1072.

41. McMullen JR, Gibson KJ, Lumbers ER, Burrell JH. Selective downregulation of AT2 receptors in uterine arteries from pregnant ewes given 24-h intravenous infusions of angiotensin II. Regul Pept. 2001;99(2-3):119-129.

42. Hladunewich MA, Kingdom J, Odutayo A, et al. Postpartum assessment of the renin angiotensin system in women with previous severe, early-onset preeclampsia. J Clin Endocrinol Metab. 2011;96(11): 3517-3524.

43. Schmieder RE. End organ damage in hypertension. Dtsch Arztebl Int. 2010;107(49):866-873.

44. Jones ES, Black MJ, Widdop RE. Angiotensin AT2 receptor contributes to cardiovascular remodelling of aged rats during chronic AT1 receptor blockade. J Mol Cell Cardiol. 2004;37(5):1023-1030.
45. Tea BS, Der Sarkissian S, Touyz RM, Hamet P, deBlois D. Proapoptotic and growth-inhibitory role of angiotensin II type 2 receptor in vascular smooth muscle cells of spontaneously hypertensive rats in vivo. Hypertension. 2000;35(5):1069-1073.

46. Akishita M, Iwai M, Wu L, et al. Inhibitory effect of angiotensin II type 2 receptor on coronary arterial remodeling after aortic banding in mice. Circulation. 2000;102(14):1684-1689.

47. Brede M, Hadamek K, Meinel L, et al. Vascular hypertrophy and increased P70S6 kinase in mice lacking the angiotensin II AT(2) receptor. Circulation. 2001;104(21):2602-2607.

48. Wu L, Iwai M, Nakagami H, et al. Effect of angiotensin II type 1 receptor blockade on cardiac remodeling in angiotensin II type 2 receptor null mice. Arterioscler Thromb Vasc Biol. 2002;22(1):49-54.

49. Paulis L, Becker ST, Lucht K, et al. Direct angiotensin II type 2 receptor stimulation in $\mathrm{N} \omega$-nitro-L-arginine-methyl ester-induced hypertension: the effect on pulse wave velocity and aortic remodeling. Hypertension. 2012;59(2):485-492.

50. Rehman A, Leibowitz A, Yamamoto N, Rautureau Y, Paradis P, Schiffrin EL. Angiotensin type 2 receptor agonist compound 21 reduces vascular injury and myocardial fibrosis in stroke-prone spontaneously hypertensive rats. Hypertension. 2012;59(2):291-299.

51. Benndorf RA, Krebs C, Hirsch-Hoffmann B, et al. Angiotensin II type 2 receptor deficiency aggravates renal injury and reduces survival in chronic kidney disease in mice. Kidney Int. 2009;75(10):1039-1049.

52. Ma J, Nishimura H, Fogo A, Kon V, Inagami T, Ichikawa I. Accelerated fibrosis and collagen deposition develop in the renal interstitium of angiotensin type 2 receptor null mutant mice during ureteral obstruction. Kidney Int. 1998;53(4):937-944.

53. Chang S-Y, Chen Y-W, Chenier I, Tran SLM, Zhang S-L. Angiotensin II type II receptor deficiency accelerates the development of nephropathy in type I diabetes via oxidative stress and ACE2. Exp Diabetes Res. 2011;2011:521076.

54. Jöhren O, Dendorfer A, Dominiak P. Cardiovascular and renal function of angiotensin II type-2 receptors. Cardiovasc Res. 2004;62(3): 460-467.

55. Wenzel UO, Krebs C, Benndorf R. The angiotensin II type 2 receptor in renal disease. J Renin Angiotensin Aldosterone Syst. 2010;11(1): 37-41.

56. Stoll M, Steckelings UM, Paul M, Bottari SP, Metzger R, Unger T. The angiotensin AT2-receptor mediates inhibition of cell proliferation in coronary endothelial cells. J Clin Invest. 1995;95(2):651-657.

57. Matavelli LC, Huang J, Siragy HM. Angiotensin $\mathrm{AT}_{2}$ receptor stimulation inhibits early renal inflammation in renovascular hypertension. Hypertension. 2011;57(2):308-313.

58. Gelosa P, Pignieri A, Fändriks L, et al. Stimulation of AT2 receptor exerts beneficial effects in stroke-prone rats: focus on renal damage. J Hypertens. 2009;27(12):2444-2451.

59. Kaschina E, Grzesiak A, Li J, et al. Angiotensin II type 2 receptor stimulation: a novel option of therapeutic interference with the renin-angiotensin system in myocardial infarction? Circulation. 2008;118(24): 2523-2532.

60. Jing F, Mogi M, Sakata A, et al. Direct stimulation of angiotensin II type 2 receptor enhances spatial memory. J Cereb Blood Flow Metab. 2012;32(2):248-255.

61. Dhande I, Ali Q, Hussain T. Proximal tubule angiotensin AT2 receptors mediate an anti-inflammatory response via interleukin-10: role in renoprotection in obese rats. Hypertension. 2013;61(6):1218-1226.

62. Ohshima K, Mogi M, Jing F, et al. Direct angiotensin II type 2 receptor stimulation ameliorates insulin resistance in type 2 diabetes mice with PPAR $\gamma$ activation. PLoS One. 2012;7(11):e48387. 
Integrated Blood Pressure Control

Dovepress

\section{Publish your work in this journal}

Integrated Blood Pressure Control is an international, peer-reviewed open-access journal focusing on the integrated approach to managing hypertension and risk reduction. Treating the patient and comorbidities together with diet and lifestyle modification and optimizing healthcare resources through a multidisciplinary team approach constitute key

features of the journal. This journal is indexed on American Chemical Society's Chemical Abstracts Service (CAS). The manuscript management system is completely online and includes a very quick and fair peerreview system, which is all easy to use. Visit http://www.dovepress.com/ testimonials.php to read real quotes from published authors.

Submit your manuscript here: http://www.dovepress.com/integrated-blood-pressure-control-journal 